Emerson Wagner Mainardes Fundação Instituto Capixaba de Pesquisa em Contabilidade Economia e Finanças Av. Fernando Ferrari, 1358, Boa Vista, 29075505 - Vitória, ES - Brazil emerson@fucape.br Phone: +2740094444
Alexandre dos Santos Cerqueira

Fundação Instituto Capixaba de Pesquisa em Contabilidade Economia e Finanças

Rua Tenente Mário

Francisco de Brito,

100, Enseada do Suá,

29055225 - Vitória, ES - Brazil

alexandre.cerqueira@bombeiros.es.gov.br

Phone: +2731374430
UDK 339.3:35

Original scientific article

Received: July 3, 2014

Accepted for publishing: December 21, 2014

\title{
MEASURING THE INTERNAL-MARKET ORIENTATION IN THE PUBLIC SECTOR
}

\begin{abstract}
The application of internal marketing in organizations has been researched by scholars for nearly three decades, but literature has little empirical research in the public sector. There is a latent debate on the relevance of internal marketing in the public sector, given the need to provide a more effective service to the citizens. Given the possibility that the internal-market orientation is an antecedent of job satisfaction, the objective of this research was to measure the level of internal market orientation in the public sector, and the Military Fire Department of the State of Espírito Santo (MFDESS) was surveyed using quantitative research. The instrument for data collection was a structured questionnaire, which follows the model used by Gounaris (2006) in research with employees of a hotel chain in Greece. 522 firefighters were surveyed. The choice of this organization was due to the importance of the service performed and the society visibility, given the direct relationship with life and assets of the taxpayers. Therefore, the level of job satisfaction of firefighters is relevant for the achievement of excellence in their missions. The results showed that firefighters have the perception that there is little internal-market orientation in the Military Fire Department and the level of job satisfaction is low. The research result converged with the literature on the direct relationship of the internal-market orientation with job satisfaction. Furthermore, the research concluded that job satisfaction is influenced by the identification of the exchange of value, segment internal market, job description, management concern and training.
\end{abstract}

Keywords: internal marketing, public sector, internal-market orientation, job satisfaction. 


\section{Introduction}

In recent years, researchers worldwide have been concerned about public sector performance (Brewer, Hupe, 2007), and encouraged the adoption of management practices from the private sector in the public sector for improvement (Osborne, Gaebler, 1992; Robertson, Seneviratne, 1995). This government modernization and its agencies are supported by the understanding that the public sector should provide a more efficient and effective service to the citizens (Caemmerer, Wilson, 2011). Moreover, the public sector organizations have been under pressure from different stakeholder groups as well as an increase of the public demand (Mawby, Worthington, 2002). In this sense, there is an ongoing debate about the relevance and role of marketing in the public sector services (Butler, Collins, 1995). Andrews and Boyne's (2010) research on the improvement of public services highlighted discoveries that related organizational performance with the influences of the organization's internal characteristics.

Therefore, there is an evident link between the enhancement of human capital and the understanding of it as internal customers. Thus, the spread of a favourable organizational environment and employee satisfaction have become competitive advantages and, because there is a direct relationship between the commitment of internal customers and the performance of organizations, the need of the internal market orientation is emphasized (Gounaris, 2006). Farias (2010) highlighted that service provider organizations require excellence in services as a goal, and that this is related to the performance of employees.

Nearly three decades ago, internal marketing was introduced with the intent of solving the problem of consistently delivering high quality services (Farias, 2010). Papasolomou (2006) emphasized that the purpose of internal marketing is to motivate and educate the employee, through the use of techniques, approaches and concepts of marketing aiming at the success of the organization in the external market. Hogg and Carter (2000) classified internal marketing as a part of market orientation, Piercy and Morgan (1990) related it to the marketing mix and Deng and Darg (1994) and Kohli, Jaworski and Kumar (1993) tried to adapt means to measure the internal market orientation.
In this sense, Lings and Greenley (2005) stated that internal marketing is an approach that results in increased levels of employee's satisfaction.

Therefore, the culture of the service was gradually strengthened and highlighted the role of the employee in the organization's performance (Anokise, Ahmed, 2009). According to this view, the focus is on valuing employees, through the internal market orientation. Gounaris (2008) indicated that there is a direct relationship between internal customer satisfaction and external customer satisfaction, and there is evidence that the internal market orientation can be an antecedent of job satisfaction. Still, there are practical cases that demonstrate the positive effects of internal marketing on employee satisfaction, such as the Gounaris' (2006) research in hotels in Greece, where there was a direct relationship between the internal market orientation and participation in decisions, empowerment and employee satisfaction, and Mawby and Worthington's (2002) research on the England police service, which addresses the need for a serious direction in the use of internal marketing to transform the police force into a police service.

This study addresses the internal market orientation in public sector services. The organization chosen was the Fire Brigade of Espírito Santo (Military Fire Department of the State of Espírito Santo or MFDESS), which is a state public organization, belonging to the public security sector that has as constitutional mission to provide security services to prevent and act in cases of fire and panic, firefighting, search and rescue, civil defence and fire expertise. MFDESS' work is a type of service that is directly related to the lives and assets of the taxpayers, who are considered here as the consumers of the firefighters' services. Employee satisfaction is relevant for the successful performance of the tasks listed above. Therefore, the problem of this research is to determine the level of Internal Market Orientation in the Fire Brigade of Espírito Santo.

Thus, the aim of this study was to measure the level of internal market orientation in MFDESS through quantitative research on the military firefighter personnel of the State of Espírito Santo.

The application of internal marketing in organizations has little empirical research in the public sector (Boyne, 2004). Evidence on the impact of management and organizational features are limited (Boyne, 2004), mainly because most studies are conducted in public organizations in the United States and Western Europe, and little is known 
about public organizations in developing countries (Mawby, Worthington, 2002). The same authors, in a study on the English police, stated that many principles and techniques must emerge from marketing services, one of which is internal marketing. Gounaris (2006) argues that the internal market orientation is an important component for the development of internal marketing and suggests as future research applying the model in different types of organizations.

Therefore, it is expected that this study will bring contributions to the literature regarding the internal marketing orientation in the public sector. Nevertheless, the study can bring practical contributions to other public sector organizations, through the knowledge of the measurement of internal market orientation in a public organization and understanding of its relationship with job satisfaction. This is also relevant for companies that have similarities with the researched organization, such as rosters, emergency work, operational training and strict hierarchy.

In the article, firstly, a literature review was made focusing on the elements of internal marketing and the internal market orientation, and its relationship with employee satisfaction. Then, the methodology was explained and the results were presented. The article ends with a discussion of the results and conclusions, in which the study's limitations were discussed as well as the contributions and suggestions for future researchers and practitioners.

\section{Literature Review}

\subsection{Elements of Internal Marketing in Service}

Three decades ago, internal marketing (IM) was introduced as a tool that could consistently raise the quality of services provided. Although not a new concept, the concept and scope of IM is not yet fully understood (Farias, 2010).

Although there is a diverse range of grouped elements under IM's aegis and a variety of concepts, it is agreed that the client is within the organization. Thus, Berry (1981) points out that one can visualize the internal marketing as follows: employees are the internal customers and the activities of these employees are the inner products. Therefore, the emphasis should be on providing internal products that satisfy the needs and desires of these internal customers, given the organization's goals. Bansal et al. (2001) stated that the current economy, increa- singly service-oriented, demands that companies attract and retain these internal customers to ensure a sustainable competitive advantage.

Accordingly, in the service organizations, the quality of service is directly related to the quality of human resources. Farias (2010) indicates that most of the early work on IM focused on motivation and employee satisfaction and Berry et al. (1976) stated that the way found to achieve employee satisfaction was to treat them as customers. According to Rafiq and Ahmed (2003), as well as external customers, internal customers wish to have their needs met, as this will increase their satisfaction and thus increase the possibility of generating external satisfaction and loyalty. Therefore, although the IM refers to all functions of the organization, the focus is on human resource management (Collins and Payne, 1991).

It is noteworthy that one of the elements of IM presented by Bansal et al. (2001) is regarding job security. It consists of offering employees reasonable assurance that they will not be fired, regardless of economic cycles. This guarantee is inherent to the members of the organization researched in this study, as the firefighters qualify by passing a public exam to enter in the Military Fire Brigade; they automatically receive this guarantee of stability. The same author adds that another element is extensive training, since the front-line staff must have the necessary knowledge and expertise to ensure the quality and effectiveness of services provided. In the case of the Military Fire Brigade, training is of paramount importance, since the corporation deals daily with the lives and assets of people. Therefore, the organizational efforts to retain the best employees, including benefits and promotions received according to their performance, are positively related to job satisfaction and loyalty to the organization.

Furthermore, it is important for organizations to act transparently as this is an important ally in the quest for the employees' trust and therefore a key element for IM. It is necessary to openly share relevant information about the organization, for example, strategic planning and financial performance. Nevertheless, in line with the training and transparency, Bansal et al. (2001) indicate that organizations with emphasis on internal customers, should engage in the reduction of status distinctions, as this can create a sense of inferiority in some members and therefore a reduction in motivation. This concern is not a routine part of internal market orientation practiced by the corporation in focus, since the patents and graduations are acquired gradually 
by time of service and professional qualification, however, it can be an important aspect to be considered in the perspective of the military firefighters' satisfaction.

\subsection{Application of Internal Marketing and Job Satisfaction}

Facing the proposition that the application of IM can be an antecedent of organizational commitment, Abzari et al. (2011) clarify that employees are the main organizational actors and internal marketing is a tool that proposes actions to educate, inform, reward and manage human resources and thereby increase the level of the service delivery. In short, in realizing this concern of the company, employees tend to commit to organizational success and show the feelings of satisfaction and motivation at work. Under this view, Lings (2000) concludes that the success factor of internal marketing is associated with the reach of employee satisfaction. Furthermore, Abzari et al. (2011) reported that among the benefits derived from the IM practice, it is important to highlight the improvement in service quality and reducing the rate of staff turnover.

It is noteworthy that it was verified that internal marketing activities stimulate central behaviours related to core activity, as well as encourage the improvement and practice of additional behaviours as, for example, the exercise of citizenship, as seen in the study of Abzari and Ghujali (2011) with employees of Bank Melli in Iran. This is related to the image that the organization transmits to the market, and in this light, the organization studied in this research is relevant, since it works directly with the life and assets of individuals. Therefore, it is noticed that the level of internal market orientation can provide benefits beyond increased quality of services obtained through reaching the motivation of its employees.

Abzari et al. (2011) also conducted a study on the effects of internal marketing on organizational commitment in the hotel industry in Iran and found that these effects occur directly or indirectly through the internal market orientation. In this research, the evidence that internal marketing is positively related to organizational commitment was proven, once the relationship between the variables was significant. It is worth adding that the study by Shekary et al. (2012) analysing the application of IM in the banking industry through a structural equation model between two variables, obtained similar results regarding the positive and significant effect on employee commitment.

\subsection{Internal Market Orientation (IMO)}

According to Rafiq and Ahmed (2000), there are many studies on IM, but it is verified that few organizations apply IM. The concept of what IM is and what it can do for the organization can be a reason for limiting its use due to confusion that many companies have about the concept of IM (Gounaris et al., 2004). Day (1988) states that it derives from the organizational culture and during the 90 s a stream of researchers allowed the understanding of the paradigm of marketing orientation (Kohli, Jaworski, 1990; Dalgic, 1998; Gray et al, 1998.; Day, 1999), whose results show that without a market-oriented organizational culture, marketing programs alone are not sufficient to produce satisfactory results oriented to marketing (Gounaris, 2006) and also that the applications of external marketing have a part in the implementation of internal marketing ( Berry, 1987). Making an analogy, it may be possible that internal marketing is not widely adopted due to lack of cultural value in organizations regarding IMO, similarly to what happens regarding intra-organizational cultural resistance in the orientation of marketing in general. Gounaris (2006) reported in the survey of its theoretical research that only in 2004 was the first study on internal market orientation by Lings produced. However, the study was theoretical. Later, Lings and Greenley (2005), through empirical examination, focused on the IM effort of organizations and Gounairs (2006) presented a theoretical model in his empirical research on the internal market orientation in a hotel chain in Greece. Internal market orientation has as predecessor the external market orientation (Pierce, 1995; Conduit, Mavondo, 2001). The basis of organization commitment required to produce value for its internal market by understanding their needs, should be replicated in the commitment level of the organization with its customers (Slater, Narver, 1999). This allows a symmetric orientation and ensures a balance of internal and external orientation at the organization level (Pitt and Foreman, 1999). Through the internal market orientation, IM becomes more effective and this strengthens the competitive positioning in external markets (Gronroos, 1983; Ahmed et al, 2003). 
Lings (2004) described three pillars of IMO and its components. Gounaris (2006) suggested an alternative model for adoption of IMO, based on the Lings' (2004) model, which has taken into account a hierarchical approach between the three pillars and their components (Figure 1). The same author related the sub dimensions of the model according to important IM aspects in organizations: participation in decision making (Gronroos, 1983), empowerment (Rafiq and Ahmed, 2000) and job satisfaction (Scheineider et al, 2003). The result of the empirical study by Gounaris (2006) demonstrated a positive correlation with the IMO aspects described above.

Figure 1 Model of conceptualizing IMO Gounaris (2006) - hierarchical approach procedures and reveals that these employees tend to keep the internal systems and processes (Claver et al., 1999; Parker, Bradley, 2000). Many public services have their ways of management based on market orientation (Walker et al., 2011). This movement towards market orientation has been going on for more than 30 years, in order to offer reforms in the bureaucratic structure to improve productivity and performance of the public sector (Hood, 1991; Lane, 2000; Pollitt, Bouckaert, 2011). Given this context, the implementation of the IMO as support for IM and market orientation is necessary. Mawby and Worthington (2002) in a survey conducted by British police suggested that convincing internal stakeholders of the need for internal marketing is a necessary predecessor.

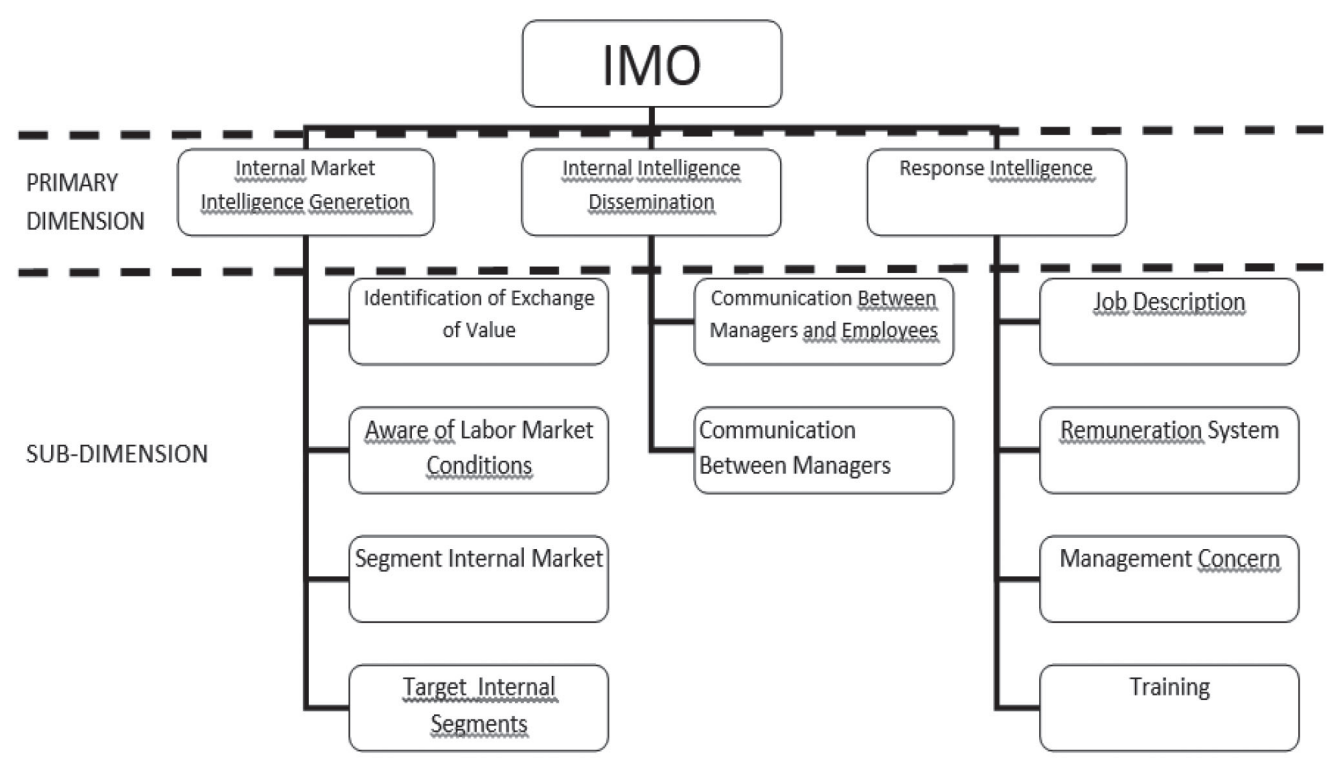

Source: Adapted from Gounaris (2006)

\subsection{Proposed Theoretical Model of IMO for the Public Sector}

Researches in the public sector are being motivated by the understanding that there are differences between the preferences of employees in the public and private sector (Perry and Porter, 1982; Snyder, Osland, 1996). The traditional view in relation to public sector employees is that there is a great inflexibility and resistance to change internal bureaucratic
In this context, although the model by Gounaris (2006) demonstrated the totality of the aspects approach of IMO, he was directed at the private sector and does not provide the specifics of the public sector, therefore in the proposed model in this study (Figure 2) the sub dimension related to the conditions of the labor market was withdrawn. Moreover, the sub dimensions in this research were only related to the aspect of job satisfaction. Gounaris (2006) wrote that job satisfaction is an important goal of IM programs and a key indicator of performance considering the performance of the organization in relation to the IMO. 
Figure 2 Structure of Internal Market Orientation and job satisfaction

EXTERNAL PERIMETER - SOCIETY

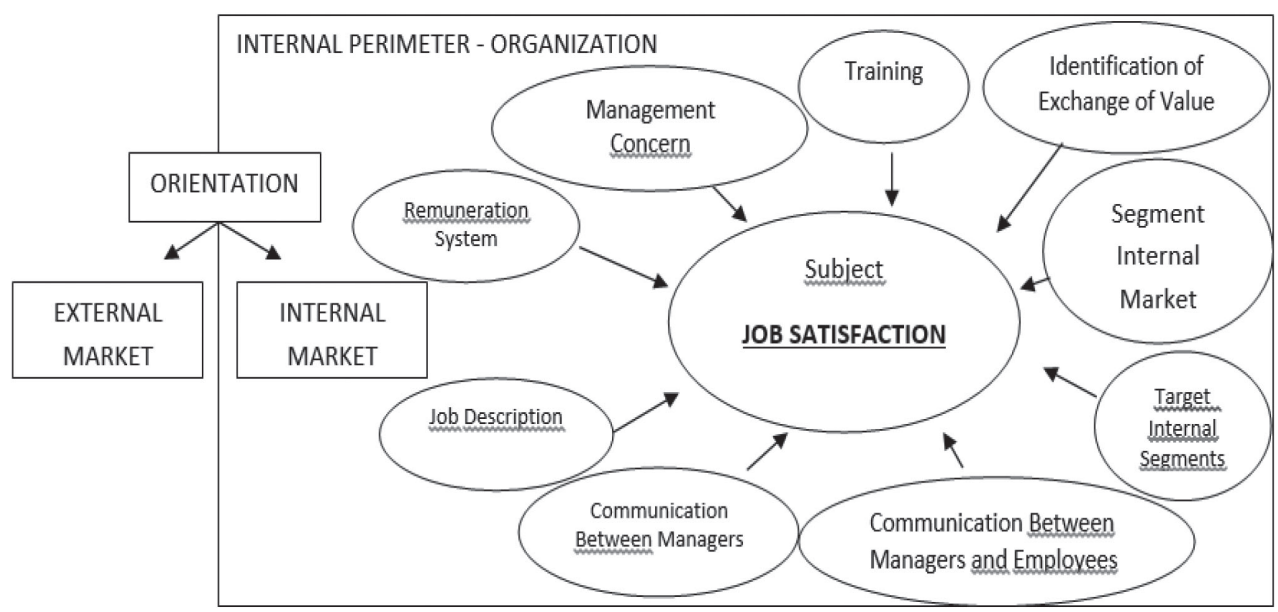

\section{Source: Authors}

\section{Research methodology}

Given the purpose of the study, the research method used was the descriptive quantitative with the transversal cut to measure the level of IMO for the public sector.

The research population consisted of public sector employees, because the existing literature offers little empirical research in the public sector (Boyne, 2004). The choice of MFDESS as a field of study is

Table 1 Sociodemographic questions of sample characteristics due to its relevance to society. The random sample was represented by the Military Firefighters Brigade of the State of Espírito Santo in Brazil, with a total of 1,300 firefighters, chosen due to the importance of the type of service performed, and their visibility in society. The MFDESS is a public state organization belonging to the public security sector whose mission is saving lives and reducing property damage. The work of MFDESS is a type of service that is directly related to the lives and assets of the taxpayers, who are considered here as customers of firefighter services, and employee satisfaction is relevant for the successful performance of the tasks listed above.

\begin{tabular}{|c|c|c|c|c|}
\hline 1 AGE (AGE) & up to 25 years & 26 to 35 years & $\begin{array}{c}36 \text { to } 45 \\
\text { years }\end{array}$ & over 46 years \\
\hline 2 GENDER (GEN) & Male & Female & & \\
\hline $\begin{array}{l}3 \text { HIERARCHICAL LEVEL } \\
(\mathrm{HL})\end{array}$ & Corporal/Soldier & $\begin{array}{c}\text { Sublieutenant / } \\
\text { Sergeant }\end{array}$ & $\begin{array}{c}\text { Captain / } \\
\text { Lieutenant }\end{array}$ & $\begin{array}{c}\text { Colonel / Lieutenant } \\
\text { Colonel / Major }\end{array}$ \\
\hline 4 SERVICE TIME (ST) & Up to 10 years & 11 to 20 years & \multicolumn{2}{|c|}{ over 21 years } \\
\hline 5 TRAINING (TRAI) & 2 degree & 3 degree & lato senso & stricto senso \\
\hline 6 SCHEME OF SERVICE (SER) & Office & Scale & & \\
\hline 7 TYPE OF SERVICE (TYP) & Operational & \multicolumn{2}{|c|}{ Non-operational } & \\
\hline 8 LOCATION (LOC) & Vitória region & North & South & \\
\hline
\end{tabular}

Source: Authors 


\section{Table 2 Subdimensions and issues}

\begin{tabular}{|c|c|}
\hline Subdimensions & Issues \\
\hline \multirow{5}{*}{$\begin{array}{l}\text { Identification of } \\
\text { Exchange of Value }\end{array}$} & MFDESS emphasizes the understanding of my needs. \\
\hline & $\begin{array}{l}\text { My boss/commander (cmt) and I meet regularly and therefore I have the chance to say what } \\
\text { I expect from MFDESS. }\end{array}$ \\
\hline & During the year, we fill in questionnaires about our needs and desires regarding MFDESS. \\
\hline & $\begin{array}{l}\text { Our management seeks to find out what the fire departments and other public agencies and } \\
\text { private companies do to keep their employees happy. }\end{array}$ \\
\hline & Our boss considers the assessment of our job satisfaction to be an important task / cmt. \\
\hline \multirow{4}{*}{$\begin{array}{l}\text { Segment internal } \\
\text { market }\end{array}$} & $\begin{array}{l}\text { In MFDESS, firefighters are identified in groups based on individual characteristics and } \\
\text { needs. }\end{array}$ \\
\hline & Before the introduction of any change our individual needs are taken into consideration. \\
\hline & Employees are not treated in exactly the same way. Individual needs are not ignored. \\
\hline & Our individual needs are systematically assessed in MFDESS. \\
\hline \multirow{4}{*}{$\begin{array}{l}\text { Target Internal } \\
\text { Segment }\end{array}$} & $\begin{array}{l}\text { All important decisions relating to human resources policies are always tailored according to } \\
\text { our individual needs. }\end{array}$ \\
\hline & $\begin{array}{l}\text { Specific human resource policies are always considered for specific groups of firefighters } \\
\text { with common needs. }\end{array}$ \\
\hline & $\begin{array}{l}\text { No action is taken, unless there is the necessity to assess the impact on specific groups of } \\
\text { firefighters with common needs. }\end{array}$ \\
\hline & $\begin{array}{l}\text { Policies related to human resources are not uniformly applied to all. Individual needs are } \\
\text { considered. }\end{array}$ \\
\hline \multirow{5}{*}{$\begin{array}{l}\text { Communication } \\
\text { Between Managers } \\
\text { and Employees }\end{array}$} & Before changing any policy, my boss / cmt tells me step by step all I need to know. \\
\hline & My boss / cmt sincerely listens to the problems I have during the course of my work. \\
\hline & $\begin{array}{l}\text { My boss / cmt is sincerely concerned about my personal issues that may affect my producti- } \\
\text { vity. }\end{array}$ \\
\hline & My boss / cmt is never too busy to talk to me when I need it. \\
\hline & My boss / cmt spends time informing me about my tasks and my goals. \\
\hline \multirow{4}{*}{$\begin{array}{l}\text { Communication } \\
\text { Between Managers }\end{array}$} & $\begin{array}{l}\text { The heads / cmts of MFDESS meet regularly to discuss issues of subordinates and listen to } \\
\text { what other cmts have to say. }\end{array}$ \\
\hline & $\begin{array}{l}\text { If a MFDESS' firefighter has a serious problem, the heads of other departments can be } \\
\text { approached about the problem at any time. }\end{array}$ \\
\hline & $\begin{array}{l}\text { MFDESS encourages the heads / cmts to meet up and discuss among them questions about } \\
\text { their subordinates. }\end{array}$ \\
\hline & $\begin{array}{l}\text { In many cases, the solution of the problem is given by the head / } \mathrm{cmt} \text { from another depar- } \\
\text { tment and not by my boss / direct } \mathrm{cmt} \text {. }\end{array}$ \\
\hline \multirow{4}{*}{ Job Description } & My job description enables meeting my needs and goals through my work. \\
\hline & Nothing is assigned to me, unless my boss / $\mathrm{cmt}$ and I have agreed that I can actually do it. \\
\hline & The tasks I am assigned help me progress in my career in this organization. \\
\hline & $\begin{array}{l}\text { My boss / cmt has to explain my work and tasks I am assigned to the higher levels of go- } \\
\text { vernment. }\end{array}$ \\
\hline
\end{tabular}




\begin{tabular}{|c|c|}
\hline \multirow{5}{*}{$\begin{array}{l}\text { Remuneration } \\
\text { System }\end{array}$} & $\begin{array}{l}\text { When I do something extraordinary I know that I will receive some financial reward or } \\
\text { bonus. }\end{array}$ \\
\hline & My payment and annual increases are independent of the state acting as the employer. \\
\hline & My payment and annual increases are related to my qualifications and productivity. \\
\hline & All receive an annual bonus according to their productivity. \\
\hline & $\begin{array}{l}\text { My payment and annual increases are closely related to other individuals with similar quali- } \\
\text { fications working in MFDESS or other organization. }\end{array}$ \\
\hline \multirow{4}{*}{$\begin{array}{l}\text { Management Con- } \\
\text { cern }\end{array}$} & The top management of MFDESS really cares about our problems. \\
\hline & $\begin{array}{l}\text { Nothing is too expensive for our top management if it is to meet specific needs of specific } \\
\text { groups of firefighters. }\end{array}$ \\
\hline & $\begin{array}{l}\text { The top management really considers our individual needs and executes policies that reflect } \\
\text { that. }\end{array}$ \\
\hline & $\begin{array}{l}\text { The top management is focused to solve our problems and gives us the necessary support for } \\
\text { our work. }\end{array}$ \\
\hline \multirow{4}{*}{ Training } & $\begin{array}{l}\text { In this organization, training is directly related to the individual needs of each employee. } \\
\text { Mass trainings are avoided when possible. }\end{array}$ \\
\hline & A new firefighter will get support in learning the job requirements. \\
\hline & $\begin{array}{l}\text { Before the implementation of the majority of changes in the rules of the service, we always } \\
\text { get significant training regarding its impacts on our daily activities and job description. }\end{array}$ \\
\hline & $\begin{array}{l}\text { If the firefighter is moved from one department to another, he will have training on the new } \\
\text { job for a pre-specified period of time. }\end{array}$ \\
\hline Job Satisfaction & I feel satisfied to work in MFDESS \\
\hline
\end{tabular}

\section{Source: Adapted from Gounaris (2006).}

In the survey 522 firefighters of all ranks participated, who are working under the operating range or expedient in the entire state of Espirito Santo.

The data collection instrument was a structured questionnaire, which follows the model used by Gounaris (2006) with 10 sub-dimensions (Figure 1) and 43 questions. For the present study, given that the population refers to the internal market of the public sector, the sub dimension related to the situation of the labor market and 4 questions of this sub dimension were omitted. Therefore, the survey questionnaire consisted of 39 questions (independent variables) involving nine sub dimensions (independent variables) of the Gounaris (2006) model. Thus, the questionnaire was constructed in two parts: (1) questions of characterization of the socio demographic profile of the sample and (2) questions that encompass the constructs (independent variables) and job satisfaction (dependent variable). The first part (table 1) included questions (control variables) regarding age (AGE), gender (GEN), hierarchical level (HL), service time (ST), training (TRAI), scheme of service (SER), service type (TYP) and location (LOC).
The second part of the questionnaire (table 2) refers to the constructs (questions) of the theoretical model of Gounaris (2006). 39 questions address 9 sub dimensions. For the measurement of the responses the five-point Likert scale was used (1967): (1) strongly disagree, (2) partially disagree, (3) indifferent, (4) partially agree and (5) strongly agree. The method used to collect survey data was the distribution of the questionnaires to the email address of the MFDESS servers. Preliminarily, the search was authorized by the General Commander of the Military Fire Brigade, which was followed by an institutional request to firefighters to reply to the questionnaire. The pre-test questionnaire was submitted to 10 firefighters to check their understanding of the questionnaire, which presented no problems. After the pre-test, the questionnaire was applied using the tool form "GoogleDocs" and was forward electronically to commanders and heads of the military fire departments (MFD) that include the operational units, directorates, centers and administrative sessions so that their members may forward the questionnaire to their subordinates. Data collection was conducted in September 2013. To analyze the data, proportions of socio demographic categories were used for the sample charac- 
terization. Moreover, to achieve the research objectives, the descriptive statistics (mean and standard deviation) and multiple linear regression was verified.

\section{Data Analysis \\ 4.1 Sample Characterization}

Table 3 refers to the sample characterization data, obtained through the questions of socio-demographic profile.

Regarding gender, the results are classified according to the type of public organization. The MFDESS is a military organization which, because of cultural issues and physical limitations for the acceptance in the public exams, comprises more males.

Table 3 Sample Characterization
The obtained ratios in the hierarchical level are explained by the pyramidal model of organizations, where the base is larger and the top is smaller. Regarding education, there are few firefighters with an educational specialization, especially at the master's degree level.

It is noticeable that most of the respondents are aged between 26 and 35 (43.7\%), in addition, 68.6\% of the sample are corporals or soldiers of the corporation, who began serving at the corporation a relatively short time ago. As regards the time and the characterization of service, $60.1 \%$ of respondents have been working in MFDESS for 0 to 10 years, $65.9 \%$ under the work scale, $70.7 \%$ in operational and $46.1 \%$ work in the Grande Vitória region. It is noted, however, that the basis of the hierarchy of this corporation is formed by corporals or soldiers, relatively young, with 2 nd and 3rd degree completed, working operationally under the work scales in Grande Vitória.

\begin{tabular}{|c|c|c|c|}
\hline CATEGORIES & DIVISIONS & AMOUNT & PERCENTAGE \\
\hline 1 AGE (AGE) & $\begin{array}{c}\text { up to } 25 \text { years } \\
26 \text { to } 35 \text { years } \\
36 \text { to } 45 \text { years } \\
\text { over } 46 \text { years }\end{array}$ & $\begin{array}{r}118 \\
228 \\
121 \\
55\end{array}$ & $\begin{array}{l}22.6 \% \\
43.7 \% \\
23.2 \% \\
10.5 \%\end{array}$ \\
\hline 2 GENDER (GEN) & $\begin{array}{r}\text { Male } \\
\text { Female }\end{array}$ & $\begin{array}{r}467 \\
55\end{array}$ & $\begin{array}{l}89.5 \% \\
10.5 \%\end{array}$ \\
\hline 3 HIERARCHICAL LEVEL (HL) & $\begin{array}{r}\text { Corporal/Soldier } \\
\text { Sublieutenant / Ser- } \\
\text { geant } \\
\text { Captain /Lieutenant } \\
\text { Colonel / Lieutenant } \\
\text { Colonel / Major }\end{array}$ & $\begin{array}{r}358 \\
110 \\
\\
38 \\
16\end{array}$ & $\begin{array}{r}68.6 \% \\
21.1 \% \\
\\
7.2 \% \\
3.1 \%\end{array}$ \\
\hline 4. SERVICE TIME (ST) & $\begin{array}{l}\text { Up to } 10 \text { years } \\
11 \text { to } 20 \text { years } \\
\text { over } 21 \text { years }\end{array}$ & $\begin{array}{r}318 \\
116 \\
88\end{array}$ & $\begin{array}{r}60.1 \% \\
22 \% \\
16.8 \%\end{array}$ \\
\hline 5 TRAINING (TRAI) & $\begin{array}{r}2 \text { degree level } \\
3 \text { degree level } \\
\text { latu senso } \\
\text { stricto senso }\end{array}$ & $\begin{array}{r}226 \\
216 \\
70 \\
10\end{array}$ & $\begin{array}{r}43.2 \% \\
41.3 \% \\
13.4 \% \\
1.9 \%\end{array}$ \\
\hline 6 SCHEME OF SERVICE (SER) & $\begin{array}{r}\text { Office } \\
\text { Scale }\end{array}$ & $\begin{array}{l}178 \\
344\end{array}$ & $\begin{array}{l}34.1 \% \\
65.9 \%\end{array}$ \\
\hline 7 TYPE OF SERVICE (TYP) & $\begin{array}{r}\text { Operational } \\
\text { Non-operational }\end{array}$ & $\begin{array}{l}369 \\
153\end{array}$ & $\begin{array}{l}70.7 \% \\
29.3 \%\end{array}$ \\
\hline 8 LOCATION (LOC) & $\begin{array}{r}\text { Vitória region } \\
\text { North } \\
\text { South }\end{array}$ & $\begin{array}{r}241 \\
187 \\
94\end{array}$ & $\begin{array}{r}46.1 \% \\
35.9 \% \\
18 \%\end{array}$ \\
\hline
\end{tabular}

Source: Survey data 
In summary, it can be concluded that the sample represents, in general, the typical MFDESS official, showing no trends or majorities that could skew the results, thus validating the obtained sample.

\subsection{Descriptive Statistics}

Table 4 refers to the descriptive statistics of the sample, since it presents the means and standard deviations of the independent variables and the dependent variable. Regarding the satisfaction dependent variable, its average tended to neutrality (3.17) and the extent of dispersion of the values was greater than one standard deviation, indicating that the responses to the questionnaire were not consensual. Looking at the database, it can be seen that approximately $42 \%$ of respondents expressed satisfaction at work, $27 \%$ are indifferent and $31 \%$ are dissatisfied. Namely, there is an important set of MFDESS employees who are dissatisfied with the organization, something that requires in-depth studies. Indifference also needs to be better understood and a qualitative research can clarify the reasons of this contingent of dissatisfied and indifferent respondents. Table 4 also presents the means and standard deviations of the independent variables of the sub-dimensions. As for the average, a variation of 1.6 to 2.7 is verified and is generally concentrated at levels 1 and 2 of the Likert scale (strongly disagree and partially disagree) that represent low levels of IMO. The sub dimensions remuneration system and the management concern with employees exhibited the lowest average and below 2 (1.63 and 1.98). The first case can be explained by the fact of compensation following the model of public administration, where there is no criteria of productivity and efficiency. Regarding the management concern for employees, the relations between hierarchical levels are poor and subordinates may feel that the management does not care about them, or it could also be related to the military system which is part of the sample, where the subordinate has a preparation that may not value this kind of behavior. The sub dimension job description presented the best average, possibly because the activities are defined in operational procedures, where the firefighter knows his role within work teams.

The independent variables identification of exchange of value, segment of internal market, target internal segment, communication between managers, the remuneration system, the management concern and training had the lowest standard deviations with index smaller than 1 , which suggests that there is some consensus in these sub dimensions. On the other hand, the independent variables communication between managers and employees, and job description had the highest standard deviation with index greater than 1, suggesting that there was no consensus on these sub dimensions.

\section{Table 4 Descriptive Statistics}

\begin{tabular}{|l|l|r|r|}
\hline & Description & Mean & $\begin{array}{l}\text { Std. } \\
\text { Deviation }\end{array}$ \\
\hline SD1 & $\begin{array}{l}\text { Identification of } \\
\text { Exchange of Value }\end{array}$ & 2,49 &, 96 \\
\hline SD2 & $\begin{array}{l}\text { Segment Internal } \\
\text { Market }\end{array}$ & 2,10 &, 88 \\
\hline SD3 & $\begin{array}{l}\text { Target Internal } \\
\text { Segment }\end{array}$ & 2,13 &, 87 \\
\hline SD4 & $\begin{array}{l}\text { Communication } \\
\text { Between Managers } \\
\text { and Employees }\end{array}$ & 2,64 & 1,13 \\
\hline SD5 & $\begin{array}{l}\text { Communication } \\
\text { Between Managers }\end{array}$ & 2,29 &, 93 \\
\hline SD6 & Job Description & 2,73 & 1,03 \\
\hline SD7 & Remuneration System & 1,63 &, 72 \\
\hline SD8 & $\begin{array}{l}\text { Management Con- } \\
\text { cern }\end{array}$ & 1,98 &, 90 \\
\hline SD9 & Training & 2,40 & 3,17 \\
\hline Y & Job Satisfaction & 1,35 \\
\hline Valid N & listwise $)$ & & \\
\hline
\end{tabular}

Source: Survey data.

\subsection{Linear Regression}

Table 5 shows the linear regression model. The adjusted R2 indicates that satisfaction is the dependent variable explained by the covariates in $42.8 \%$ shown in Table 6 . The model has significant $F$ ratio of .030 , with $\mathrm{p}<0.05$ being significant at $95 \%$.

Moreover, the validity test of ANOVA was significant, the randomness test supports the hypothesis for randomness, the Kolmogorov-Smirnov test for adherence, in turn, supports the hypothesis of normal distribution and, finally, the homoscedasticity test supports the hypothesis of homoscedasticity. 
Table 5 Summary of the model

\begin{tabular}{|l|r|r|r|r|r|r|r|r|r|r|}
\hline \multirow{2}{*}{ Model } & \multirow{2}{*}{$\mathbf{R}$} & R Square & $\begin{array}{c}\text { Adjusted } \\
\text { R Square }\end{array}$ & $\begin{array}{c}\text { Std. Error of } \\
\text { the Estimate }\end{array}$ & $\begin{array}{c}\text { R Square } \\
\text { Change }\end{array}$ & $\begin{array}{c}\text { F } \\
\text { Change }\end{array}$ & $\begin{array}{c}\text { Change Statistics } \\
\text { df1 }\end{array}$ & $\begin{array}{c}\text { df2 } \\
\text { Chan- } \\
\text { ge }\end{array}$ & $\begin{array}{c}\text { Sig. } \\
\text { F }\end{array}$ & $\begin{array}{c}\text { Durbin- } \\
\text { Watson }\end{array}$ \\
\hline 1 &, $662 \mathrm{a}$ &, 438 &, 428 & 1,02142 &, 438 & 44,267 & 9 & 512 &, 000 & 1,967 \\
\hline
\end{tabular}

Source: Survey data

Table 6 presents the independent variables (subdimensions) that influence the dependent variable (satisfaction).

Given the sub dimensions (independent variables) of the Gounaris (2006) model, it is worth mentioning that the model presented in Table 6 showed that the following sub dimensions influence job satisfaction, according to the significance of the independent variables: identification of exchange of value (SD1), segment internal market (SD2), job description (SD6), the management concern (SD8) and training (SD9).

\section{Table 6 Coefficients}

\begin{tabular}{|c|c|c|c|c|c|c|c|c|c|c|c|c|}
\hline \multirow{2}{*}{ Model } & \multicolumn{2}{|c|}{$\begin{array}{l}\text { Unstandardi- } \\
\text { zed Coeffici- } \\
\text { ents }\end{array}$} & \multirow{2}{*}{$\begin{array}{c}\begin{array}{c}\text { Stan- } \\
\text { dar- } \\
\text { dized } \\
\text { Coeffi- } \\
\text { cients }\end{array} \\
\text { Beta }\end{array}$} & \multirow{2}{*}{$t$} & \multirow{2}{*}{ Sig. } & \multicolumn{2}{|c|}{$\begin{array}{c}95,0 \% \\
\text { Confidence } \\
\text { Interval for B }\end{array}$} & \multicolumn{3}{|c|}{ Correlations } & \multicolumn{2}{|c|}{$\begin{array}{c}\text { Collinearity } \\
\text { Statistics }\end{array}$} \\
\hline & B & $\begin{array}{l}\text { Std. } \\
\text { Error }\end{array}$ & & & & $\begin{array}{l}\text { Lower } \\
\text { Bound }\end{array}$ & $\begin{array}{l}\text { Upper } \\
\text { Bo- } \\
\text { und }\end{array}$ & $\begin{array}{l}\text { Zero- } \\
\text { order }\end{array}$ & $\begin{array}{l}\text { Par- } \\
\text { tial }\end{array}$ & Part & $\begin{array}{l}\text { Tole- } \\
\text { rance }\end{array}$ & VIF \\
\hline Constant &, 552 & ,151 & & 3,668 & ,000 & ,257 & ,848 & & & & & \\
\hline SD1 & ,381 & ,081 & ,261 & 4,730 & ,000 & ,223 & ,539 &, 582 & ,205 & ,157 & ,361 & 2,772 \\
\hline SD2 & ,205 & ,081 & 133 & 2,529 & ,012 & ,046 & ,365 & ,496 & ,111 & ,084 & ,396 & 2,526 \\
\hline SD3 &,- 133 & ,083 &,- 085 & $-1,590$ & ,113 &,- 296 & ,031 & ,438 &,- 070 &,- 053 & ,384 & 2,608 \\
\hline SD4 & ,025 &, 060 & ,021 & ,422 & 674 &,- 093 & ,144 & ,482 & 019 & ,014 & ,428 & 2,339 \\
\hline SD5 &,- 117 & ,073 &,- 081 & $-1,597$ & ,111 &,- 260 & 027 & ,436 &,- 070 &,- 053 & ,432 & 2,314 \\
\hline SD6 & ,304 & ,068 & ,233 & 4,448 & ,000 & ,170 & ,439 &, 565 & 193 & ,147 & ,402 & 2,490 \\
\hline SD7 &,- 021 & ,077 &,- 011 &,- 280 & ,780 &,- 172 & ,129 & ,331 &,- 012 &,- 009 & ,651 & 1,536 \\
\hline SD8 & ,236 & ,078 & ,158 & 3,041 & ,002 & ,084 & ,389 &, 519 & ,133 & 101 & ,406 & 2,463 \\
\hline SD9 & 190 & ,067 & 138 & 2,846 & ,005 & 059 & ,321 &, 522 & ,125 & ,094 & ,468 & 2,138 \\
\hline
\end{tabular}

\section{Discussion of Results}

The research with this sample of public sector converges with the literature on the relationship between satisfaction with the IMO, as it was found that the average sub-dimensions (independent variables) showed similarity with the average job satisfaction (dependent variable). According to Ahmed and Rafiq (2003), Gounaris (2006), Farias (2010) and Abzari et al. (2011), just like external customers, internal customers also wish to have their needs met, as this will increase their satisfaction.

Although all media from the sub dimensions are below 3 , it can be seen in Table 4 that the average job satisfaction is above 3 (3.17), verifying a small positive elasticity of job satisfaction in relation to IMO that can possibly be attributed to the fact that the activity of the firefighter is linked to vocational issues and a sense of pride in being part of an orga- 
Another important approach that should be done is that the model of Gounaris (2006) was tested with employees of a hotel chain, setting a sample of the marketing segment of the service private sector. This research was conducted in the public sector, which has specific characteristics of public administration, such as contract through public exams, job stability, absence of financial rewards, absence of mechanisms for verification of performance and excessive bureaucracy (Perry, Porter, 1982; Snyder, Osland, 1996; Mawby, Worthington 2002; Walker et al., 2011). Perhaps for this reason, it can be explained why only 6 sub-dimensions are significant in the tested model.

Still, it was observed that job satisfaction of the researched sample has $42 \%$ responses for totally agree and partially agree (4 and 5), 27\% indifferent (3) and $31 \%$ for strongly disagree and disagree partially (1 and 2), confirming the above. The number of responses for totally agree and partially agree may be associated with feelings of altruism and social recognition, where the profession of the firefighter is in first place in the opinion of the society and also the vocational issues of the employee when the individual reveals a professional ideal associated with the job. On the other hand, the average obtained may be associated with little knowledge generation among employees, poor dissemination of knowledge about the employees and inefficient response to the expectations of employees.

As for linear regression, it was found that the independent variables identification of exchange of value (SD1), segment internal market (SD2), job description (SD6), the management concern (SD8) and training (SD9) positively influence the dependent variable job satisfaction, as shown in Figure 3. In addition, the firefighters realize that MFDESS does not have IMO, and, to have IMO, it must focus on these sub-dimensions. Thus, the results of this empirical study reinforces the relationship of the orientation of the internal market of the 5 sub-dimensions mentioned above to the satisfaction of internal customers, disregarding the other sub dimensions proposed by Gounaris (2006).

Specifically, each of the major sub-dimensions is discussed in the literature. According to Lings (2004), Gounaris (2008), Abzari et al. (2011) and Abzari and Ghujali (2011), the identification of exchange of value is an important antecedent of job satisfaction and this also proved relevant in the public sector, as it is observed in the results. Another significant sub dimension, segment internal market, was approached by Hogg and Carter (2000), Gounaris (2008) and Farias (2010) as an antecedent of job satisfaction. This is to acknowledge that not all employees have the same expectations and that a focus on the specific needs of different groups in the organization can expand the overall satisfaction of employees. In the case of the public sector, as identified herein, acting on the differences seemed to be relevant to the satisfaction of the public servant.

Another antecedent to highlight is the management concern of its employees. In this study, such a sub dimension showed up as an influence of the job satisfaction of the public servant. This sub dimension was previously reported by Piercy (1995), Hogg and Carter (2000) and Gounaris (2008) as relevant to increase worker satisfaction, being here identified for the public sector employees, who feel that their manager cares about him, makes him more satisfied.

Finally, we should mention the sub dimensions job description and training. As noted in the presented study, if the public servant is well instructed as to his duties, there is the tendency to become more satisfied with his work, and so this is an antecedent to employee satisfaction, something also identified by Butler and Collins (1995), Hogg and Carter (2000), Bansal et al (2001), Collins and Payne (2001), Conduit and Mavondo (2001), Gounaris (2008) and Shekary et al. (2012). Regarding the sub dimension training, according to Kostera, Gripb and Didier (2011), the training opportunity influences job satisfaction. Shields and Ward (2001) suggest that job dissatisfaction is a predictor of turnover and the promotion and training opportunities have a great effect on job satisfaction, something also identified here and which corroborates with the studies by Ahmed et al. (2003), Lings (2004), Gounaris (2008) and Shekary et al. (2012) .

In short, it was realized that the findings corroborate in part with the literature by providing evidence that the behavior of public servants differs from the private sector workers, especially since the original model of Gounaris (2006) explains as less than half the satisfaction of the public service worker. Considering this, there are other sub dimensions to be found that are influencing the satisfaction of the public server, which can lead to improved performance of public organizations (Mawby, Worthington, 2002). 


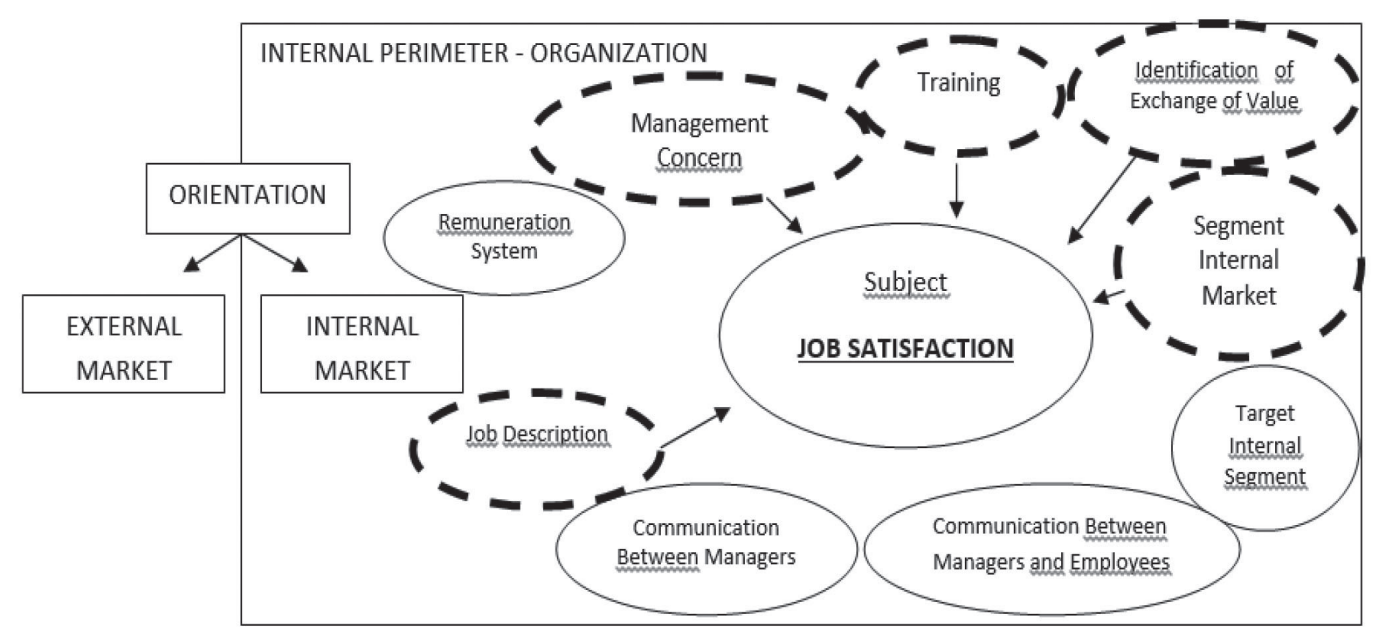

\section{Source: Authors}

\section{Conclusions}

The survey aimed to measure the level of the internal market orientation in the public sector and indicated that the perception of public servants regarding the Internal Market orientation is concentrated at levels 1 and 2 of the Likert scale (strongly disagree and disagree partially), representing low levels of IMO in the public sector. It was also found that the Gounaris (2006) model has limitations for application in the public sector because it was found that only 5 sub dimensions were significant in the regression: the variables identification of exchange of value, segment internal market, job description, the management concern and training.

It is important to highlight that the study was conducted with a public sector sample of only one public organization. Although the representation of the organization sample has been significant, public agencies have specific characteristics of the public sector area to which they belong, which indicates the possibility of internal differentiated behaviors of public organizations in relation to the IMO.

Given the context, the main finding of the research refers to the perception that public servants understand that the public sector has little concern with its Internal Market. In this context, Mawby and Worthington (2002) discuss the importance of a serious direction in the implementation of marketing to transform the police force into a police service, and highlight the internal marketing as a predecessor of the success of external marketing. Farias (2010) pointed out that service excellence is related to the performance of employees and internal marketing aims at motivating these employees, since satisfaction in the context of internal customers can interfere with success in the context of external customer satisfaction. Gounaris (2006) highlights the need for the internal market orientation, because there is a direct relationship between the commitment of internal customers and the performance of organizations. Therefore, there is evidence that the performance of the public sector, as the studied sample, may be compromised due to poor internal market orientation.

One limitation is that while the public sector is related to the provision of services, the public administration presents different configurations of the private sector (Perry, Porter, 1982; Snyder, Osland, 1996), and the model that provided the groundwork for this study is from the private sector (Gounaris, 2006) and only $42.8 \%$ of the surveyed worker satisfaction was explained by 5 of the 9 dimensions tested. This leaves room for future researches, to identify other sub dimensions that are not presented in the original model and that were not tested in this research.

Another limitation is the lack of sample heterogeneity in the public sector, because only one public organization was researched and presents itself as 
an organization that has different internal rules within the public sector because it is military.

The research presents theoretical and practical contributions. The research has theoretical contributions to the literature regarding the internal market orientation in the public sector. Furthermore, the research brought practical contributions to other organizations of public administration, through the knowledge of the level of the internal market orientation of the Military Fire Brigade of the State of Espírito Santo and the understanding of the dimensions that form the job satisfaction of public servants. Also, it is for businesses that have employees with similarities related to the researched organization, as rosters, emergency work, operati- onal training or rigid hierarchy, e.g., industrial professional firefighters, civilian firefighters, volunteer firefighters, doctors, nurses, employees of platforms and flight attendants.

For future researches, first, it is suggested to address specific indicators for the public sector that meet the particular characteristics of this research field and investigate a different sample of the public sector or a sample with several organizations in this sector. Also, suggested is the investigation of the relationship of the internal market orientation and the performance of public sector organizations, with the job satisfaction intermediate variable. 


\section{REFERENCES}

1. Abzari, M., Ghujali, T. (2011), "Examining the impact of internal marketing on organizational citizenship behavior", International Journal of Marketing Studies, Vol. 3, No. 4, pp. 95-104.

2. Abzari, M., Ghorbani, H., Madani, F. A. (2011), "The effect of internal Marketing on organizational commitment from market-orientation viewpoint in hotel industry in Iran", International Journal of Marketing Studies, Vol. 3, No. 1, p. 147-155.

3. Ahmed, P. K., Rafiq, M., Saad, N. M. (2003), "Internal marketing and the mediating role of organisational competencies", European Journal of Marketing, Vol. 37, No. 9, 1221-1241.

4. Ahmed, P. K., Rafiq, M. (2003), “Internal marketing issues and challenges”, European Journal of marketing, Vol. 37, No. 9, pp. 1177-1186.

5. Andrews, R., Boyne, G. (2010), "Debate Better Public Services: The moral purpose of public management research?", Public Management Review, Vol. 12, No. 3, 307-321.

6. Anokise, U., Ahmed, P. K. (2009), "Internal marketing: focus on practice", International Journal of Management Practice, Vol. 3, No. 4, 369-382.

7. Bansal, H. S., Mendelson, M. B., Sharma, B. (2001), "The impact of internal marketing activities on external marketing outcomes", Journal of Quality Management, Vol. 6, No. 1, 61-76.

8. Berry, L. L. (1981), “The Employee as customer”, Journal of Retail Banking, Vol. 3, pp. 25-38.

9. Berry, L. L. (1987), “Big ideas in services marketing”, Journal Service Marketing, Vol. 1, No. 1, pp. 5-10.

10. Berry, L. L., Hensel, J. S., Burke, M. C. (1976), "Improving retailer capability for effective consumerism response", Journal of Retailing, Vol. 52, No. 3, pp. 3-14.

11. Boyne, G. A. (2004), “Explaining Public Service Performance: Does Management Matter?”, Public Policy and Administration, Vol. 19, No. 4, pp. 100-117.

12. Brewer, G., Hupe, P. (2007), "Working Both Sides of the Street: Bringing Together Policy and Organizational Perspectives on Public Service Performance", paper presented at The 9th Public Management Research Association Conference, University of Arizona, October, available at: http://pmranet.org.

13. Butler, P., Collins, N. (1995), "Marketing public sector services: concepts and characteristics", Journal of Marketing Management, Vol. 11, No. 1-3, pp. 83-96.

14. Caemmerer, B., Wilson, A. (2011), "An exploration of the service orientation discrepancy phenomenon in a public sector context", The Service Industries Journal, Vol. 31, No. 3, pp. 355-370.

15. Claver, E. et al. (1999), "Public administration: From bureaucratic culture to citizen-oriented culture", International Journal of Public Sector Management, Vol. 12, No. 5, pp. 455-464.

16. Collins, B., Payne, A. (2001), "Internal marketing: a new perspective for HRM". European Management Journal, Vol. 9, No. 3, pp. 261-269.

17. Conduit, J., Mavondo, F. T. (2001), "How critical is internal customer orientation to market orientation?", Journal of business research, Vol. 51, No. 1, pp. 11-24.

18. Dalgic T. (1998), "Dissemination of market orientation in Europe A conceptual and historical evaluation", Internal Marketing Review, Vol. 15, No. 1, pp. 45-60.

19. Day G. S. (1998), "What does it mean to be market drive?", Business Strategic Review, Vol. 9, No. 1, pp. 1-14.

20. Day G. S. (1999), "Misconceptions about market orientation”, Journal Marketing Focused Management, Vol. 4, No. 1, pp. 5-16. 
21. Deng, S., Dart, J. (1994), “Measuring market orientation: A multi-factor, multi-item approach”, Journal of Marketing Management, Vol. 10, No. 8, pp. 725-742.

22. De Farias, S. A. (2010), "Internal Marketing (IM): a literature review and research propositions for service excellence", Brazilian Business Review, Vol. 7, No. 2, pp. 99-115.

23. Gounaris S. P., Avlonitis G. J., Papastathopoulou P. (2004), “Managing a firm's behavior through market orientation development: some empirical finding", Europe Journal Marketing, Vol. 38, No. 11/12, pp. 1481-1508.

24. Gounaris, S. P. (2006), "Internal-market orientation and its measurement", Journal of Business Research, Vol. 59, No. 4, pp. 432-448.

25. Gounaris, S. P. (2008), "Antecedents of internal marketing practice: some preliminary empirical evidence", International Journal of Service Industry Management, Vol. 19, No. 3, pp. 400-434.

26. Gray, B., Matear, S., Boshoff, C., Matheson, P. (1998), "Developing a better measure of market orientation", European Journal of Marketing, Vol. 32, No. 9/10, pp. 884-903.

27. Grönroos, C., Shostack, G. L. (1983). Strategic management and marketing in the service sector (p. 25). Cambridge, MA: Marketing Science Institute.

28. Hood, C. (1991), “A public management for all seasons?", Public administration, Vol. 69, No. 1, pp. 3-19.

29. Hogg, G., Carter, S. (2000), “Employee attitudes and responses to internal marketing”. Internal marketing: directions for management. London: Routledge.

30. Kohli, A. K., Jaworski, B. J. (1990), “Market orientation: the construct, research propositions, and managerial implications", The Journal of Marketing, Vol. 54, No. 2, pp. 1-18.

31. Kohli, A. K., Jaworski, B. J., Kumar, A. (1993), “MARKOR: a measure of market orientation”, Journal of Marketing research, Vol. 30, No. 4, pp. 467-477.

32. Koster, F., de Grip, A., Fouarge, D. (2011), "Does perceived support in employee development affect personnel turnover?", International Journal of Human Resource Management, Vol. 22, No. 11, pp. 2403-2418.

33. Lane, J.-E. (2000). New Public Management. London: Routledge.

34. Likert, R. (1967). The human organization: its management and values. New York: McGraw-Hill.

35. Lings I. (2000), "Internal marketing and supply chain management", Journal of Services Marketing, Vol. 14, No. 1, pp. 27-43.

36. Lings I. (2004), "Internal market orientation: constructs and consequences", Journal of Business Resource, Vol. 57, No. 4, pp. 405-413.

37. Lings, I., Greenley, G. E. (2005), "Measuring internal market orientation”, Journal of Service Research, Vol. 7, No. 3, pp. 290-305.

38. Mawby, R. C., Worthington, S. (2002), "Marketing the Police-from a Force to a Service", Journal of Marketing Management, Vol. 18, No. 9-10, pp. 857-876.

39. Osborne, D. Gaebler, T. (1992). Reinventing government - How the entrepreneurial spirit is transforming the public sector. Reading, MA: Addison-Wesley.

40. Papasolomou, I. (2006), “Can internal marketing be implemented within bureaucratic organisations?”, International Journal of Bank Marketing, Vol. 24, No. 3, pp. 194-211.

41. Parker, R., Bradley, L. (2000), "Organisational culture in the public sector: evidence from six organisations", International Journal of Public Sector Management, Vol. 13, No. 2, pp. 125-141. 
42. Perry, J. L., Porter, L. W. (1982), "Factors Affecting the Context for Motivation in Public Organizations", Academy of Management Review, Vol. 7, No. 1, pp. 89-98.

43. Piercy, N., Morgan, N. (1990), "Internal marketing: making marketing happen", Marketing Intelligence \& Planning, Vol. 8, No. 1, pp. 4-6.

44. Piercy, N. F. (1995), "Customer satisfaction and the internal market: marketing our customers to our employees", Journal of Marketing Practice: Applied Marketing Science, Vol. 1, No. 1, pp. 22-44.

45. Pitt, L. F., Foreman, S. K. (1999), "Internal marketing role in organizations: a transaction cost perspective", Journal of Business Research, Vol. 44, No. 1, 25-36.

46. Pollitt, C., Bouckaert, G. (2011). Public management reform: A comparative analysis-new public management, governance, and the Neo-Weberian state. Oxford: Oxford University Press.

47. Rafiq, M., Ahmed, P. K. (2000), "Advances in the internal marketing concept: definition, synthesis and extension", Journal of services marketing, Vol. 14, No. 6, pp. 449-462.

48. Robertson, P. J., Seneviratne, S. J. (1995), "Outcomes of planned organizational change in the public sector: A meta-analytic comparison to the private sector", Public Administration Review, Vol. 55, No. 6, pp. 547-558.

49. Schneider, B., Gunnarson, S. K., Niles-Jolly, K. (1994), "Creating the climate and culture of success", Organizational Dynamics, Vol. 23, No. 1, pp. 17-29.

50. Shekary, G. A., Moghadam, S. K., Adaryany, N. R., Adaryany, I. H. (2012), "The impact of internal marketing on organizational commitment in banking industry through structural equation modeling", Interdisciplinary journal of contemporary research, Vol. 3, No. 9, pp. 18-28.

51. Shields, M. A., Ward, M. (2001), "Improving nurse retention in the National Health Service in England: the impact of job satisfaction on intentions to quit", Journal of health economics, Vol. 20, No. 5, pp. 677-701.

52. Slater, S. F., Narver, J. C. (1999), “Market-oriented is more than being customer-led”, Strategic Management Journal, Vol. 20, No. 12, pp. 1165-1168.

53. Snyder, M. M., Osland, J. (1996), "Public and private organizations in Latin America: a comparison of reward preferences", International Journal of Public Sector Management, Vol. 9, No. 2, pp. 15-27.

54. Walker, R. M., Brewer, G. A., Boyne, G. A., Avellaneda, C. N. (2011), "Market Orientation and Public Service Performance: New Public Management Gone Mad?", Public Administration Review, Vol. 71, No. 5, pp. 707-717. 


\title{
MJERENJE ORIJENTIRANJA NA UNUTARNJE TRŽIŠTE U JAVNOM SEKTORU
}

\begin{abstract}
SAžEtaK
Znanstvenici istražuju primjenu unutarnjega marketinga u organizacijama gotovo tri desetljeća, ali u literaturi se ne može pronaći puno empiričkih istraživanja u javnom sektoru. Prisutna je latentna rasprava o relevantnosti unutarnjeg marketinga u javnom sektoru, s obzirom na potrebu pružanja učinkovitije usluge građanima. S obzirom na mogućnost da orijentiranju na unutarnje tržište prethodi zadovoljstvu poslom, cilj je ovoga istraživanja izmjeriti razinu orijentacije na unutarnje tržište u javnom sektoru, a istraživanje provedeno na Vojnoj vatrogasnoj postrojbi države Espírito Santo provedeno je uz pomoć kvantitativnoga istraživanja. Kao instrument za prikupljanje podataka korišten je strukturirani upitnik koji prati model kojeg je Gounaris (2006.) koristio u istraživanju sa zaposlenicima hotelskog lanca u Grčkoj. U anketi su sudjelovala 522 vatrogasca. Ova je organizacija odabrana zbog važnosti usluge koju pruža te vidljivosti u društvu, s obzirom na neposredan odnos sa životom i imovinom poreznih obveznika. Stoga je razina zadovoljstva poslom kod vatrogasaca važna za postizanje izvrsnosti u njihovim misijama. Rezultati su pokazali da vatrogasci imaju percepciju da je orijentiranje na unutarnje tržište u Vojnoj vatrogasnoj službi slabo te da je razina zadovoljstva poslom niska. Rezultati istraživanja poklapaju se s literaturom o neposrednom odnosu između orijentiranja na unutarnje tržište i zadovoljstva poslom. Nadalje, zaključak istraživanja je da je zadovoljstvo poslom pod utjecajem prepoznavanja razmjene vrijednosti, segmenta unutarnjega tržišta, opisa radnoga mjesta, interesa uprave i obuke.
\end{abstract}

Ključne riječi: unutarnji marketing, javni sektor, orijentacija unutarnjeg marketinga, zadovoljstvo poslom 